\title{
Lactobacillus ingluviei sp. nov., isolated from the intestinal tract of pigeons
}

\author{
Margo Baele, ${ }^{1}$ Marc Vancanneyt, ${ }^{2}$ Luc A. Devriese, ${ }^{1}$ Karen Lefebvre, ${ }^{2}$ \\ Jean Swings ${ }^{2}$ and Freddy Haesebrouck ${ }^{1}$
}

\author{
Correspondence \\ Margo Baele \\ Margo.Baele@rug.ac.be
}

\author{
${ }^{1}$ Department of Pathology, Bacteriology and Poultry Diseases, Faculty of Veterinary Medicine, \\ Ghent University, Salisburylaan 133, B-9820 Merelbeke, Belgium \\ ${ }^{2}$ BCCM/LMG Bacteria Collection, Laboratory of Microbiology, Faculty of Sciences, \\ Ghent University, K. L. Ledeganckstraat 35, B-9000 Gent, Belgium
}

Lactic acid bacteria were isolated from the crop and intestines of pigeons. One group of strains, showing similar genomic patterns after screening with tRNA intergenic spacer PCR, could not be identified to the species level. Sequencing of the 16S rRNA gene of one representative strain revealed about $96 \%$ similarity to sequences from Lactobacillus fermentum and Lactobacillus mucosae. Determination of the DNA base composition, DNA-DNA hybridization experiments, SDS-PAGE of whole-cell proteins and biochemical testing confirmed that the seven strains studied constitute a single novel Lactobacillus species, for which the name Lactobacillus ingluviei

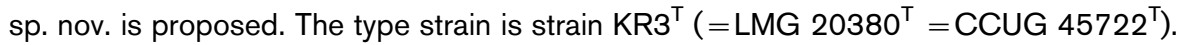

\section{INTRODUCTION}

In a previous study on the enterococcal, streptococcal and lactobacillar crop flora of pigeons, Lactobacillus agilis was the most frequently isolated species and was present in eight of 10 pigeon crops examined (Baele et al., 2001a). Five of the 10 pigeons were also colonized by an unknown bacterium, which showed a tRNA intergenic spacer PCR (tDNA-PCR) fingerprint different from those of all lactic acid bacteria available in the database. tDNA-PCR makes use of universal bacterial primers directed against the edges of the tRNA genes, amplifying the spacers between the genes. After determination of the amplicon lengths by means of capillary electrophoresis, a peak pattern is obtained that is characteristic for a given species (Baele et al., 2000, 2001b, 2002). The taxonomic position of this group of strains was investigated in a polyphasic study.

\section{METHODS}

Strains. Seven analogous strains were isolated from crop-sac samples of five euthanized pigeons (A-E, Table 1) belonging to different pigeon-fanciers; this was performed both anaerobically on Rogosa SL agar (Becton-Dickinson) and on Slanetz \& Bartley agar (Oxoid) in a $\mathrm{CO}_{2}$-enriched atmosphere after $48 \mathrm{~h}$ incubation. From two of these pigeons, strains with identical tDNA fingerprints were also

Abbreviation: tDNA-PCR, tRNA intergenic spacer PCR.

The GenBank accession number for the $16 \mathrm{~S}$ rRNA sequence of strain LMG $20380^{\top}$ is AF333975.

A tDNA-PCR-based dendrogram including a wider sample of reference taxa is available as supplementary material in IJSEM Online (http:// ijs.sgmjournals.org/). isolated from intestinal samples. In the present study, these isolates were investigated further (Table 1). The strains were designated as $\mathrm{KR}^{\mathrm{T}}$ (=LMG 20380 ${ }^{\mathrm{T}}$ ), KR10 (=LMG 20381), KR16 (=LMG 20382), KR36 (=LMG 20383), KR47 (=LMG 20384), KR21 (=LMG 20978) and KR45 (=LMG 20979), and all were deposited in the BCCM/LMG Bacteria Collection, Ghent, Belgium.

tDNA-PCR. Cultures were grown overnight on MRS (de ManRogosa-Sharpe) agar (Lab M) under anaerobic conditions at $37^{\circ} \mathrm{C}$. For DNA preparation, a small loopful of cells was suspended in $20 \mu$ lysis buffer $(0.25 \%$ SDS, $0.05 \mathrm{M} \mathrm{NaOH})$ and heated at $95^{\circ} \mathrm{C}$ for $5 \mathrm{~min}$. After brief centrifugation at $16000 \mathrm{~g}$, lysed cells were resuspended in $180 \mu \mathrm{l}$ distilled water and centrifuged again for $5 \mathrm{~min}$ at $16000 \mathrm{~g}$ to remove the cell debris. Supernatants were used as the DNA in the PCR or were frozen at $-20^{\circ} \mathrm{C}$ until further use.

The PCR was carried out using outwardly directed tRNA-gene consensus primers T5A (5'-AGTCCGGTGCTCTAACCAACTGAG$\left.3^{\prime}\right)$ and T3B (5'-AGGTCGCGGGTTCGAATCC-3') as described earlier (Baele et al., 2000). Cycle reactions were carried out as described previously.

The samples were subjected to capillary electrophoresis using an ABI-Prism 310 Genetic Analyzer (Perkin-Elmer Cetus). Electrophoregrams were normalized using internal size standards with GENESCAN analysis software, version 2.1. Electrophoregrams were compared with the database by using a software program developed at our laboratory (Baele et al., 2000, 2001b). After calculation of a distance matrix, clustering was done with NEIGHBOR software (PHYLIP; http://evolution.genetics.washington.edu/phylip.html), using the UPGMA algorithm.

165 rDNA sequencing. DNA extraction was performed as described for tDNA-PCR analysis. 16S rDNA was amplified using the commercially available Qiagen Taq Mastermix, to which primers $\alpha \beta$-NOT (5'-TCAAACTAGGACCGAGTC- $\left.3^{\prime}\right)$ and $\omega_{\mathrm{MB}}$ (5'-TACCTTGTTACTTCACCCCA- $3^{\prime}$ ) were added at a concentration of $0 \cdot 2 \mu \mathrm{M}$. The PCR products were sequenced using the BigDye 
Table 1. Strains used in this study

\begin{tabular}{|lcll|}
\hline Strain & Pigeon & Origin & Isolation medium \\
\hline KR10 (= LMG 20381) & A & Crop & Slanetz \& Bartley \\
KR21 (= LMG 20978) & B & Crop & Slanetz \& Bartley \\
KR47 (= LMG 20384) & B & Intestines & Rogosa SL \\
KR36 (= LMG 20383) & C & Crop & Rogosa SL \\
KR45 (= LMG 20979) & C & Intestines & Rogosa SL \\
KR3 $^{\mathrm{T}}(=$ LMG 20380 \\
KR16 $(=$ LMG 20382 $)$ & D & Crop & Slanetz \& Bartley \\
& & Crop & Slanetz \& Bartley \\
\hline
\end{tabular}

Terminator sequencing kit (Applied Biosystems) and primers $\mathrm{pD}$, Gamma $^{*}, 3$ and $\mathrm{O}^{*}$ (Coenye et al., 1999), as described before (Baele et al., 2001), and determined on an automatic DNA sequencer (ABI Prism 310 Genetic Analyzer). The electrophoregrams were exported and converted to GeneBase (Applied Maths) using Abiconv (Applied Maths). The sequences were compared with the NCBI GenBank by using the BLAST search tool. Phylogenetic analysis was performed using the Bionumerics software (Applied Maths) after including the consensus sequence in an alignment of small ribosomal subunit sequences collected from GenBank. Multiple alignment was calculated using an open gap penalty of $100 \%$ and a unit gap penalty of $0 \%$. A tree was constructed using the neighbour-joining method.

DNA base composition. Strains LMG $20380^{\mathrm{T}}$ and LMG 20383 were grown on MRS broth and incubated for $24 \mathrm{~h}$ at $37^{\circ} \mathrm{C}$ under anaerobic conditions. High-molecular-mass native DNA was extracted from $0 \cdot 75-1.25 \mathrm{~g}$ wet weight of cells by using the protocol described by Pitcher et al. (1989), with the following modifications: the washed cell pellet was resuspended and lysed in a buffer $(10 \mathrm{mM}$ Tris/HCl, $100 \mathrm{mM}$ EDTA, pH 8.0) containing RNase (200 $\mu \mathrm{g} \mathrm{ml}^{-1}$; Sigma), mutanolysin (100 $\mathrm{U} \mathrm{ml}^{-1}$; Sigma) and lysozyme $\left(25 \mathrm{mg} \mathrm{ml}^{-1}\right.$; Serva) for $1 \mathrm{~h}$ at $37^{\circ} \mathrm{C}$. Before the addition of GES reagent, proteinase $\mathrm{K}\left(200 \mu \mathrm{g} \mathrm{ml}^{-1}\right.$; Merck) was added to the mixture for $15 \mathrm{~min}$.

For determination of the DNA base composition, DNA was enzymically degraded into nucleosides and then separated by HPLC as described previously (Vancanneyt et al., 2001).

DNA-DNA hybridization experiments. High-molecular-mass native DNA was prepared as described above for determination of the DNA base composition. DNA-DNA hybridizations were performed as described by Vancanneyt et al. (2001) by using a microplate method and fluorescence measurements for calculation of the binding values. Hybridizations were performed at $41{ }^{\circ} \mathrm{C}$.

PAGE analysis of whole-cell protein. Cells were cultivated as indicated for determination of DNA base composition. Whole-cell protein extracts were prepared and PAGE was then performed as described by Pot et al. (1994). Registration of the protein patterns, normalization of the densitometric traces, pattern storage and grouping of the strains using Pearson's product-moment correlation coefficient $(r)$ and UPGMA analysis were performed as described by Pot et al. (1994) by using the software GelCompar (Applied Maths).

Biochemical activity and growth characteristics. All seven strains were tested biochemically as described previously. Growth was tested on MRS agar at $25,30,37$ and $42^{\circ} \mathrm{C}$ under anaerobic conditions. The influence of the gas atmosphere was determined: growth yield under aerobic and anaerobic $\left(\mathrm{H}_{2}+\mathrm{CO}_{2}\right.$, GasPak Plus; $\mathrm{BBL})$ conditions and in a $5 \% \mathrm{CO}_{2}$-enriched atmosphere were

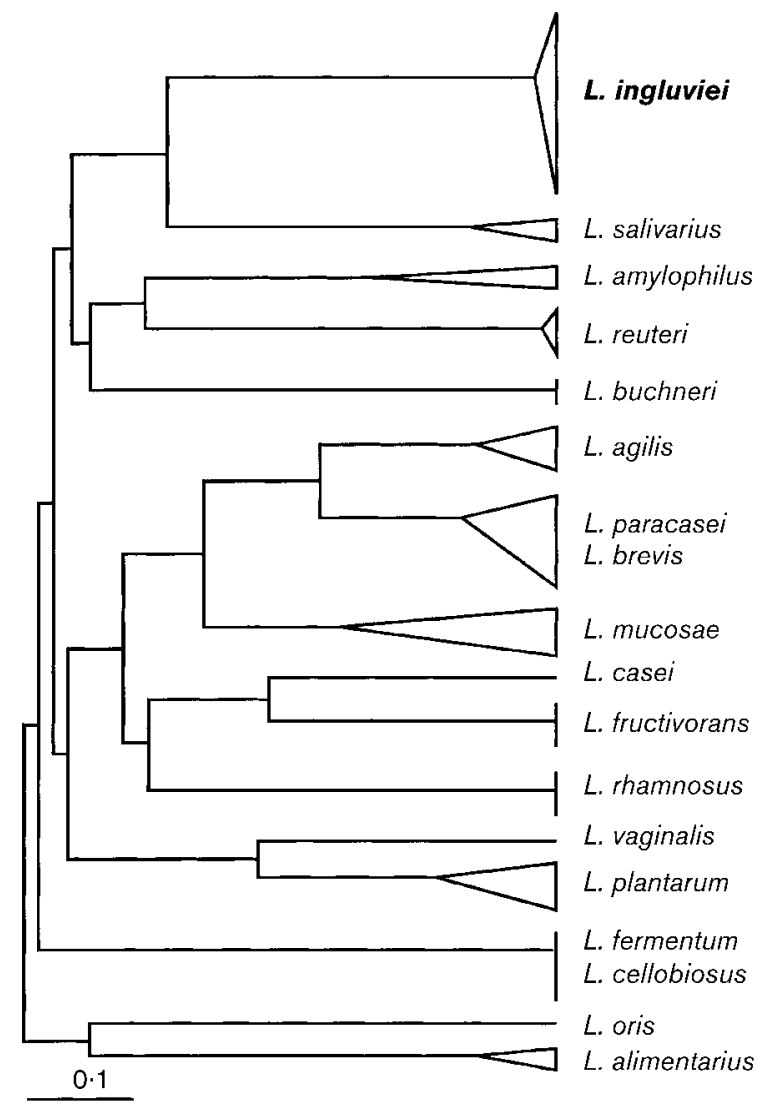

Fig. 1. Dendrogram obtained from tDNA-PCR fingerprints, after similarity calculation with in-house software and clustering with UPGMA using the program NEIGHBOR. The bar represents a distance of $10 \%$. A dendrogram including a wider sample of reference taxa is available as supplementary material in IJSEM Online (http://ijs.sgmjournals.org/).

compared. Carbohydrate acidification tests were carried out with API $50 \mathrm{CH}$ galleries according to the instructions of the manufacturer (bioMérieux).

\section{RESULTS AND DISCUSSION}

\section{Genotypic studies}

Screening of the isolates by tDNA-PCR revealed an atypical pattern different from all profiles of lactic acid bacteria available in the database. Capillary electrophoresis of the amplicons revealed mean peak positions of $162 \cdot 5,176 \cdot 5$, $185 \cdot 5$ and $255 \cdot 2$ bp. Numerical analysis clearly confirmed the aberrant position of the strains (Fig. 1).

To determine their phylogenetic position, one representative strain, LMG $20380^{\mathrm{T}}$, was selected for $16 \mathrm{~S} \mathrm{rDNA}$ sequence analysis. Highest similarities, of 96 and $95.4 \%$, were obtained to the sequences of Lactobacillus fermentum and Lactobacillus mucosae, respectively (Fig. 2). These values clearly indicate that strain LMG $20380^{\mathrm{T}}$ belongs 


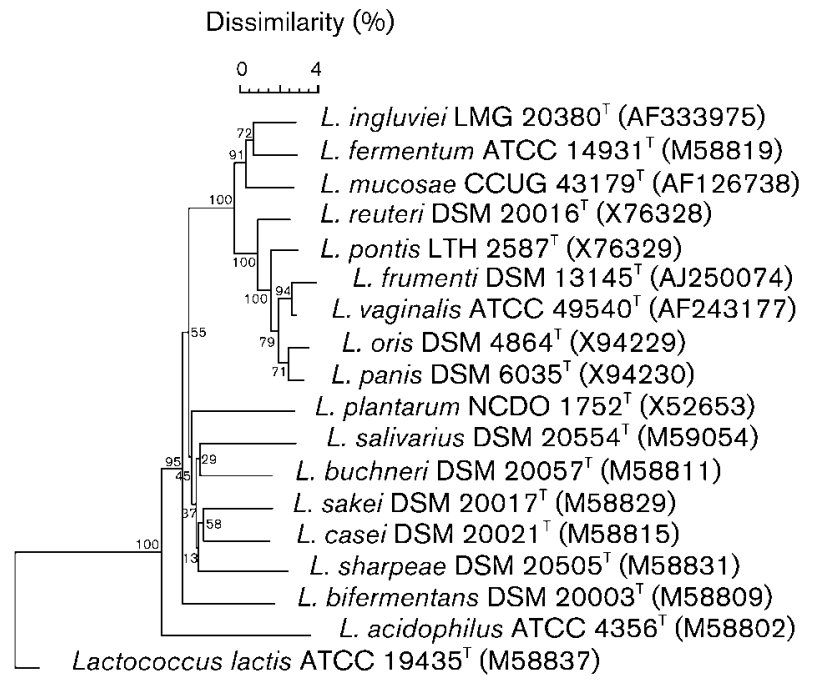

Fig. 2. Phylogenetic tree showing the relationships among Lactobacillus ingluviei sp. nov., related species of the Lactobacillus reuteri group and species representing different lineages within the genus Lactobacillus. The tree was constructed by neighbour-joining analysis of a distance matrix from a multiple-sequence alignment. Lactococcus lactis was used as the outgroup, and bootstrap values are indicated at the branchpoints (100 trees resampled). Accession numbers are given.

to the genus Lactobacillus, but the similarities are too low for possible relatedness at the species level with one of the currently described Lactobacillus species (Stackebrandt \& Goebel, 1994).

Two strains, LMG $20380^{\mathrm{T}}$ and LMG 20383, were subsequently subjected to DNA-DNA hybridization analysis. A relatedness value of $77 \%$ confirmed that the two strains constitute a single genomic species. Determination of the DNA G $+C$ content of the two strains revealed respective values of $49 \cdot 4$ and $49 \cdot 2 \mathrm{~mol} \%$.

\section{Phenotypic studies}

SDS-PAGE analysis of whole-cell proteins yielded highly similar patterns in the seven strains, confirming that they represent a single species. The profiles were different from all patterns of lactic acid bacteria in the database (data not shown), confirming their separate species status. The patterns of three of the strains and of L. fermentum and L. mucosae, their phylogenetically closest neighbours, are shown in Fig. 3.

The growth characteristics of all seven strains were compared. Six strains showed smooth colonies on MRS agar, but strain LMG 20383 showed dry, crumbly colonies. On Columbia blood agar, the strains appear streptococcuslike and without further testing, might be confused with the latter taxon. Other growth characteristics and differentiating phenotypic features between the novel taxon and its phylogenetic neighbours, L. fermentum and L. mucosae, are described below and are summarized in Table 2.

The results of the present study allowed us to assign the strains to a novel species, for which we propose the name Lactobacillus ingluviei sp. nov.

\section{Description of Lactobacillus ingluviei sp. nov.}

Lactobacillus ingluviei (in.glu'vi.ei. L. n. ingluvies crop sac; L. gen. n. ingluviei of a crop sac).

Cells are Gram-positive, non-motile, very short, plump rods, rapidly decolorizing in the Gram-stain procedure. Cells mostly occur singly or in pairs, and some appear to be slightly longer than others. They are non-sporulating and catalase-negative. Colonies are white and smooth or crumbly and dry. Growth is enhanced under anaerobic conditions and also slightly in the presence of $5 \% \mathrm{CO}_{2}$, compared with aerobic growth. Better growth is obtained at $42^{\circ} \mathrm{C}$ than at $37^{\circ} \mathrm{C}$. No growth occurs at $25^{\circ} \mathrm{C}$ and growth is poor at $30^{\circ} \mathrm{C}$. The strains grow as non-haemolytic streptococcus-like colonies on Columbia blood agar with

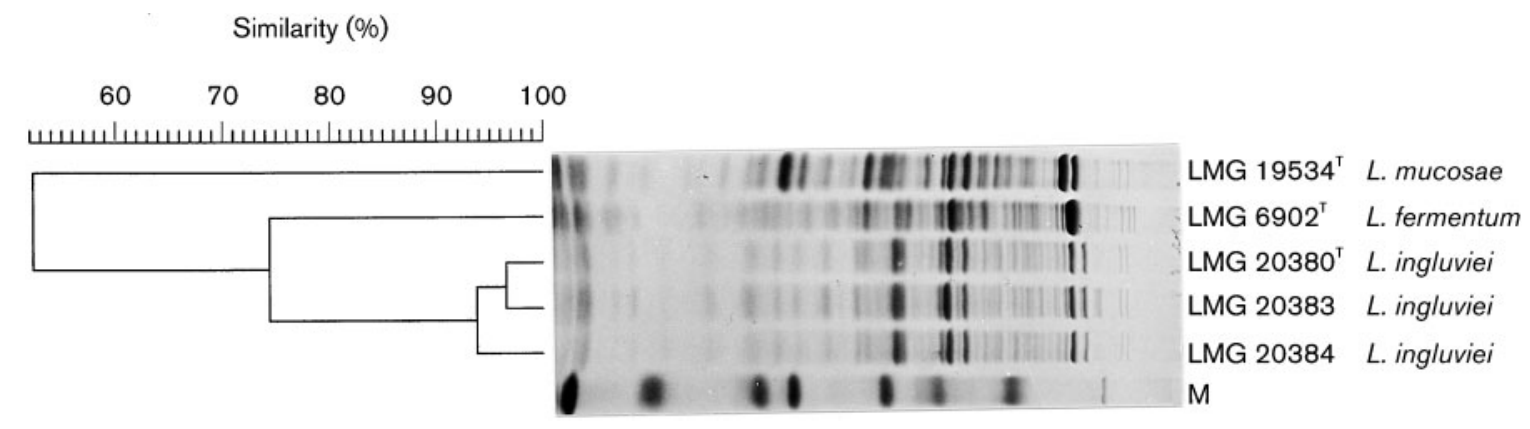

Fig. 3. Protein profiles of three representative strains of $L$. ingluviei sp. nov., L. mucosae and $L$. fermentum and the corresponding dendrogram derived from UPGMA cluster analysis of correlation coefficients $r$ (expressed as percentages). The molecular mass markers (lane M) are (from left to right): lysozyme, 14500; trypsin inhibitor, 20100 ; trypsinogen, 24000 ; carbonic anhydrase, 29000 ; glyceraldehyde-3-phosphate dehydrogenase, 36000 ; egg albumin, 45000 ; BSA, 66 000; and $\beta$-galactosidase, 116000. 
Table 2. Characteristics that differentiate L. ingluviei sp. nov. from closely related species

Data for reference taxa were obtained from Hammes \& Vogel (1995) and Roos et al. (2000). Characters are scored as follows: + , positive; $\mathrm{D}$, strain-dependent; $\mathrm{D}+$, usually positive; - , negative.

\begin{tabular}{|lccc|}
\hline $\begin{array}{l}\text { Production } \\
\text { of acid from: }\end{array}$ & L. ingluviei & L. fermentum & L. mucosae \\
\hline D-Fructose & + & + & - \\
Galactose & - & + & $\mathrm{D}$ \\
Melibiose & - & + & $\mathrm{D}+$ \\
\hline
\end{tabular}

diameters of up to $0.5 \mathrm{~mm}$. Acid is produced from L-arabinose, $\mathrm{D}$-fructose, methyl $\beta$-xyloside, ribose, sucrose and D-xylose. No acid is produced from adonitol, amygdalin, D-arabinose, D- or L-arabitol, arbutin, cellobiose, dulcitol, erythritol, D- and L-fucose, galactose, $\beta$-gentiobiose, 2-ketogluconate, 5-ketogluconate, $N$-acetylglucosamine, glycerol, glycogen, methyl $\alpha$-D-glycoside, inositol, inulin, lactose, D-lyxose, mannitol, methyl $\alpha$-D-mannoside, melezitose, melibiose, rhamnose, salicin, sorbitol, L-sorbose, starch, D-tagatose, trehalose, D-turanose, xylitol or L-xylose. Acidification of aesculin, gluconate (weak reaction), D-glucose, maltose, D-mannose and D-raffinose is variable. The DNA G $+\mathrm{C}$ content is $49 \mathrm{~mol} \%$ and the characteristic tDNA-PCR fingerprint is composed of fragments with lengths of $162 \cdot 5,176 \cdot 5,185 \cdot 5$ and $255 \cdot 2 \mathrm{bp}$, as determined by fluorescent capillary electrophoresis. The habitat is pigeon crop and intestines. The type strain is strain $\mathrm{KR} 3^{\mathrm{T}}$ $\left(=\mathrm{LMG} 20380^{\mathrm{T}}=\right.$ CCUG $\left.45722^{\mathrm{T}}\right)$.

\section{ACKNOWLEDGEMENTS}

This work was supported by the Research Fund of the University of Ghent, Belgium (Codenr. BOF98/GOA/014). The authors are grateful to Arlette Vandekerckhove for skilled technical assistance.

\section{REFERENCES}

Baele, M., Baele, P., Vaneechoutte, M., Storms, V., Butaye, P., Devriese, L. A., Verschraegen, G., Gillis, M. \& Haesebrouck, F. (2000). Application of tRNA intergenic spacer PCR for the identification of Enterococcus species. J Clin Microbiol 38, 4201-4207.

Baele, M., Devriese, L. A. \& Haesebrouck, F. (2001a). Lactobacillus agilis is an important component of the pigeon crop flora. J Appl Microbiol 91, 488-491.

Baele, M., Storms, V., Haesebrouck, F., Devriese, L. A., Gillis, M., Verschraegen, G., De Baere, T. \& Vaneechoutte, M. (2001b). Application and evaluation of the interlaboratory reproducibility of tRNA intergenic length polymorphism analysis (tDNA-PCR) for identification of Streptococcus species. J Clin Microbiol 39, 1436-1442.

Baele, M., Vaneechoutte, M., Verhelst, R., Vancanneyt, M., Devriese, L. A. \& Haesebrouck, F. (2002). Identification of Lactobacillus species using tDNA-PCR. J Microbiol Methods 50, 263-271.

Coenye, T., Falsen, E., Vancanneyt, M., Hoste, B., Govan, J. R. W., Kersters, K. \& Vandamme, P. (1999). Classification of Alcaligenes faecalis-like isolates from the environment and human clinical samples as Ralstonia gilardii sp. nov. Int J Syst Bacteriol 49, 405-413.

Hammes, W. P. \& Vogel, R. F. (1995). The genus Lactobacillus. In The Genera of Lactic Acid Bacteria, pp. 19-54. Edited by J. B. Wood-Brian \& W. H. Holzapfel. London: Blackie.

Pitcher, D. G., Saunders, N. A. \& Owen, R. J. (1989). Rapid extraction of bacterial genomic DNA with guanidium thiocyanate. Lett Appl Microbiol 8, 151-156.

Pot, B., Vandamme, P. \& Kersters, K. (1994). Analysis of electrophoretic whole-organism protein fingerprints. In Chemical Methods in Prokaryotic Systematics, pp. 493-521. Edited by M. Goodfellow \& A. G. O'Donnell. Chichester: Wiley.

Roos, S., Karner, F., Axelsson, L. \& Jonsson, H. (2000). Lactobacillus mucosae sp. nov., a new species with in vitro mucus-binding activity isolated from pig intestine. Int J Syst Evol Microbiol 50, 251-258.

Stackebrandt, E. \& Goebel, M. (1994). Taxonomic note: a place for DNA-DNA reassociation and $16 \mathrm{~S}$ rRNA sequence analysis in the present species definition in bacteriology. Int J Syst Bacteriol 44, 846-849.

Vancanneyt, M., Snauwaert, C., Cleenwerck, I. \& 8 other authors (2001). Enterococcus villorum sp. nov., an enteroadherent bacterium associated with diarrhoea in piglets. Int J Syst Evol Microbiol 51, 393-400. 